\title{
IMPLEMENTASI INSIDE LEGAL THEORY DALAM PEMBANGUNAN HUKUM NASIONAL MELALUI PENDEKATAN HUKUM ISLAM
}

\author{
Burhanuddin Susamto \\ Fakultas Syariah UIN Maulana Malik Ibrahim Malang \\ burhanuddins.uin@gmail.com
}

\begin{abstract}
Abstrak
Inside Legal Theory is a theory of religious law enforcement for their followers internally. The fact that Islamic law enforcement juridically is always considered treaten diversity of other religions which can lead to disintegration. Even by the reason diversity, certain group (kelompok anti syariat Allah) able to pursue the idealism of Islamic law envorcement in bigest Islamic country having muslim people as a majority. Diversity is sunatullah, so that Islamic law enforcement is not necessary vis a vis with diversity. Through Inside Legal Theory, Islamic law enforcement internally is constitutional right of Indonesian muslim people so there is no one able to its opposite.

Inside Legal Theory adalah teori pemberlakuan hukum agama secara internal bagi pemeluknya. Kenyataan bahwa upaya pemberlakuan hukum Islam secara yuridis formal di Indonesia sering dianggap mengancam kebeagamaan umat lainnya, sehingga berpotensi menimbulkan disintegrasi. Bahkan dengan alasan keberagamaan tersebut, kelompok tertentu (kemomok anti syariat Allah) ternyata telah mampu mengubur citacita pemberlakuan hukum Islam di negara yang mayoritas berpenduduk Muslim terbesar di dunia ini. Keberagamaan adalah sunatullah, karenanya pemberlakuan hukum Islam tidak perlu vis a vis dengan keberagamaan. Melalui Inside Legal Theory, pemberlakuakuan hukum Islam secara internal merupakan hak konstitusional umat Islam Indonesia sehingga serorangpun tidak akan mampu medebatnya.
\end{abstract}

Kata Kunci: Inside Legal Theory, Hukum Islam, Hukum Nasional

Hukum $^{1}$ adalah seperangkat peraturan yang terkait erat dengan perbuatan manusia. Pada hakikatnya, semua perbuatan manusia akan dimintai pertanggungjawaban, ${ }^{2}$ sehingga keberadaanya tidak akan pernah lepas dari hukum yang berlaku. ${ }^{3}$ Dikatakan demikian sebab hukum selain memuat batasan-batasan larangan

\footnotetext{
${ }^{1}$ Abd. Rahman Dahlan, Ushul Fiqh (Jakarta: Penerbit Amzah, 2010), h. 33

${ }^{2}$ QS.Al-Muddatsir [74]: 38.

${ }^{3}$ QS. Al-Jatsiyah [45]: 18.
}

yang tidak boleh dilanggar (makruh/ haram), juga memuat ketentuan petunjuk yang dapat mengarahkan manusia untuk berbuat sebaik mungkin. Petunjuk itu ada yang diwujudkan dalam bentuk perintah (wajib/ sunnat) maupun kebolehan (mubah) untuk berbuat atau tidak berbuat sesuatu. ${ }^{4} \mathrm{Hikmah}$ keluasan aspek kebolehan yang melekat pada hukum adalah bertujuan untuk memberikan kemudahan

\footnotetext{
${ }^{4}$ Amir Syarifuddin, Ushul Fiqh I, (Jakarta: Kencana, 2011), h. 336
} 
kepada manusia agar dapat berkreasi sesuai fitrah kemanusiaannya.

Manusia adalah mahluk sosial yang hidup di wilayah tertentu untuk saling berinteraksi guna memenuhi kebutuhannya. Pada hakekatnya, manusia diciptakan Allah SWT dalam keadaan fitrah melalui perpaduan antara unsur jasmani (QS.Ali-Imran [3]:59 dan QS.As-Sajdah [32]:7) dan ruhani (QS.Al-Hijr [15]:29 dan QS.As-Sajdah [32]:9). Kedua unsur penciptaan manusia itulah yang kemudian menjelma menjadi kebutuhan hidup yang harus dipenuhi. Karena itu untuk memenuhi kebutuhannya, setiap manusia perlu bermasyarakat yang pola relasinya terikat oleh norma-norma yang berlaku.

Kehidupan manusia terus berkembang seiring dengan kemajuan ilmu pengetahuan dan teknologi (IPTEK). Pesatnya kemajuan ilmu pengetahuan dan teknologi, menyebabkan peradaban manusia juga berkembang secara pesat. Diantara bentuk perkembangan ialah adanya pergeseran peradaban manusia dari budaya primitif tradisional menjadi budaya modern. ${ }^{5}$ Bahkan begitu pesatnya perubahan tersebut, terkadang sampai menimbulkan apa yang disebut keterkejutan budaya (culture shock) ${ }^{6}$ akibat kegagalan menyikapi perubahan. Jika perubahan tidak berdampak pada prilaku menyimpang tentu tidak ada masalah, tetapi bagaimana jika perubahan tersebut diikuti oleh penyimpangan terhadap nilai-nilai moral dan kebenaran?

Untuk mengarahkan kepada perbuatan yang baik dan menghindari penyimpangan, diperlukan perangkat hukum yang berlaku di tengah kehidupan manusia. Hukum yang

${ }^{5}$ Perlu dipahami bahwa dalam kehidupan modern bukan berarti mengesampingkan sesuatu yang lama hingga larut dalam pusaran medernitas tersebut. Sesuatu peninggalan yang masih tetap relevan dalam kehidupan modern lintas generasi adalah ilmuilmu syar'i baik dari aspek aqidah maupun hukumhukumNya.

${ }^{6}$ Culture Shock merupakan sebuah keadaan dimana seseorang merasa tidak nyaman dan seperti merasakan sebuah ancaman bagi kesejahteraannya ketika berada dilingkungan yang baru didatangi/ditempati. Lihat, Ling Toomey, Communicating Across Culture (New York: The Gulford Press, 1999), h. 245 baik ialah hukum yang memiliki kewibawaan di hadapan manusia sebagai subjek hukum. Agar dapat merekayasa kehidupan manusia di masyarakat (tool of social engineering), ${ }^{7}$ maka hukum selain dituntut untuk ideal, juga harus bersifat manusiawi. Ideal artinya bahwa hukum yang diberlakukan harus benar-benar memuat integrasi nilai-nilai (kebenaran, keadilan, kemanfaatan,dan lain-lain) dalam perspektif ilahiyah sehingga dapat memotivasi subjek hukum. Sedangkan hukum bersifat manusiawi artinya hukum harus dapat dijalankan oleh manusia secara universal, kecuali ada sebabsebab tertentu yang kemungkinan menghalangi pemberlakuannya.

Peradaban manusia (human civilization) terus mengalami perkembangan seiring dengan perubahan waktu. Untuk mengarahkan kehidupan manusia modern menuju peradaban yang lebih ideal, diperlukan perangkat hukum, baik yang berlaku secara formal maupun non formal. Hukum yang berlaku secara yuridis formal adalah peraturan perundangundanganyang disusun dan ditetapkan oleh lembaga negara yang berwenang (legalized institutions), sehingga pemberlakuannya bersifat mengikat secara umum. Sedangkan yang dimaksud dengan hukum berlaku secara non formal adalah hukum yang hidup (living law) ${ }^{8}$ dan berkembang dengan sendirinya di tengah masyarakat. ${ }^{9}$

Hukum non formal bersifat dinamis sering perkembangan peradaban umat manusia itu sendiri. Artinya apa yang diharapkan masyarakat bahwa hukum tersebut bersifat tetap, maka

\footnotetext{
${ }^{7}$ Roscoe Pound, Interpretation of Legal History (Harvard University Press, 1946), h. 160

${ }^{8}$ Eugen Ehrlich, Fundamental Principles of Sociology of Law (Cambridge: Harvard University Press, 1936), h. 6

${ }^{9}$ Hukum yang hidup dan berkembang dengan sendirinya di masyarakat misalnya hukum yang berkaitan dengan kepercayaan agama dan adat istiadat. Living law (hukum non formal) di masyarakat ada yang diadopsi menjadi peraturan perundangundangan oleh lembaga Negara dan ada yang tidak. Ada tidaknya pengadopsian hukum non formal tergantung dari kebutuhan dan dinamika politik yang berkembang.
} 
hukum itupun akan tetap keberadannya. Begitupula sebaliknya, apabila hukum diyakini masyarakat bersifat berubah, maka hukum itupun akan berubah sesuai kebutuhan masyarakat. Perubahan hukum non formal di masyarakat dapat terjadi kapan pun tanpa harus menunggu proses politik hukum (legal policy). Jadi keberadaan hukum non formal dapat dipastikan bersifat akomodatif terhadap perubahan masyarakat. Berbeda dengan hukum non formal, hukum yang berlaku secara yuridis formal (peraturan perundang-undangan), cendrung tidak bersifat akomodatif terhadap perubahan masyarakat. Peradaban masyarakat selalu bersifat dinamis, sedangkan peraturan perundang-undangan dianggap cendrung bersifat statis. Dikatakan statis karena peraturan perundang-undangan tidak bisa berubah setiap saat mengikuti perubahan masyarakat. Untuk merubah peraturan perundang-undangan, diperlukan proses politik yang membutuhkan waktu lama. Bahkan peraturan perundang-undangan yang telah berlaku tidak akan dirubah, kecuali pemerintah menganggap perlu merubahnya. Ketergantungan pada legal policy itulah yang menyebabkan peraturan perundang-undangan tidak akomodatif terhadap perubahan peradaban manusia.

Disamping itu, pemberlakuan peraturan perundang-undangan sebagai hukum negara selalu bersifat top down. Artinya dengan system top down, masyarakat dipaksa untuk mentaati hukum Negara. ${ }^{10}$ Pelanggaran terhadap hukum negara menyebabkan pelakunya dikenai sanksi hukum sesuai dengan bentuk dan bidang pelanggaranya. Pemberlakuan hukum negara sering menimbulkan persoalan, terutama ketika hukum negara tidak dibangun berdasarkan jiwa masyarakat/ bangsanyanya. ${ }^{11}$ Jiwa masyarakat selalu dibangun atas dasar

${ }^{10}$ Kekuasaan negara adalah kekuasaan yang sah (legal), sedangkan apabila muncul kekuasaan lain maka kekuasaan tersebut tidak sah (illegal). Oleh karena itu negara bersifat memaksa, memonopoli, dan menyeluruh.

${ }^{11}$ Dalam hal ini, pendapat Von Savigny bahwa pembelakuan hukum harus mencerminkan jiwa rakyatnya (Volksgeist) sepertinya ada benarnya. Lihat, Surya Prakash Sinha, Jurisprudence Legal Philosophy kepercayaan (keagamaan/ adat) yang penuh dengan nilai-nilai. Karena itu mengesampingkan eksistensi kepercayaan masyarakat (hukumhukum agama) dalam pembentukan peraturan perundang-undangan, pasti akan menyebabkan produk hukum negara mengalami kekeringan nilai. ${ }^{12} \mathrm{Hukum}$ negara yang kekeringan nilai akan mengalami krisis keibawaan di hadapan manusia sebagai subjek hukum. Tanda-tanda hukum negara mengalami krisis kewibawaan adalah banyaknya penyimpangan terhadap nilai-nilai moral dan pelanggaran yang terjadi di tengah upaya penegakan hukum itu sendiri (law enforcement). Dalam hal ini, pemberlakuan hukum negara dapat dikatakan belum mampu menjadi celupan (sibghah) untuk mewarnai masyarakat agar berprilaku yang baik. Bahkan sanksi hukum yang diterapkan oleh negara seolah tidak menimbulkan efek jera.

Untuk membangun perundang-undangan sebagai hukum negara yang penuh dengan muatan nilai-nilai, ${ }^{13}$ lembaga pemerintah perlu mengadopsi hukum yang menjadi kepercayaan masyarakatnya. Jika di suatu masyarakat banyak hukum yang berlaku berdasarkan kepercayaan (agama) maupun tradisi (legal pluralism), maka hukum yang diadopsi seharusnya hukum yang berperadaban (civilized law). Jika hukum yang diadopsi oleh lembaga negara adalah hukum yang tidak berperadaban (uncivilized law), maka dikhawatirkan masyarakatnya akan mengalami krisis moral. Jika diamati secara mendalam, sesungguhnya Indonesia adalah

\footnotetext{
in A Nutshell (West Publishing Co, 1993), h. 206

${ }^{12}$ Nilai-nilai suatu hukum sesungguhnya dapat digali dari sumber hukum. Berdasarkan Pasal 2 Undang-Undang Nomor 12 Tahun 2011 tentang pembentukan peraturan perundang undangan, sumber dari segala sumber hukum adalah Pancasila. Pancasila dikatakan sebagai sumber hukum karena adanya sila pertama, yaitu Ketuhanan Yang Maha Esa.
}

${ }^{13}$ Banyak prinsip yang seharusnya dimuat pada nilai-nilai suatu hukum, misalnya prinsip kebenaran, keadilan, kemanfaatan, dan lain-lain. Untuk menghindari dari tarik menarik kepentingan manusia (human interest), nilai-nilai hukum tersebut harus mendasarkan pada perspektif ketuhanan (transcendentalvalues).Karenanilai-nilaitransendental menyatu dengan hukum, maka mentaati hukum merupakan bagian dari ibadah. 
sebuah negara yang sedang mengalami krisis moral. Banyaknya prilaku menyimpang dalam segala dimensi kehidupan adalah bukti nyata adanya krisis moral tersebut. Adapun yang menjadi sebab utama terjadinya krisis moral adalah karena rendahnya standar moral yang melekat pada norma hukum yang berlaku. Menurut penulis, hukum yang berlaku saat ini lebih banyak didominasi oleh aturan yang bersifat prosedural, sehingga tidak menyentuh pada aspek subtansinya. Padahal subtansi hukum bukanlah aturan-aturan yang bersifat prosedural, melainkan norma hukum yang digali dari kepercayaan masyarakat. Islam sebagai salah satu agama yang dipercayai masyarakat, tentu memiliki konsep hukum untuk dijadikan bahan pengembangan subtansi hukum di Indonesia.

Manusia yang baik kecendrungan akan menghasilkan produk hukum yang baik. Begitu pula sebaliknya, manusia yang buruk kecendrungan akan menghasilkan produk hukum yang buruk pula. Manusia yang baik adalah manusia berperadaban yang menjungjung tinggi nilai-nilai ketuhanan (alqiyam al-ilahiyah) sebagaimana dicontohkan melalui misi kenabian. Manusia yang tidak baik adalah manusia jahiliyah yang tidak berperadaban. Kenyataan bahwa kehidupan manusia di Indonesia sebagai subjek hukum ada yang sudah berperadaban (madaniyah) dan ada yang terbelakang (jahiliyah). Keberagamaan inilah yang kemudian menyebabkan sistem hukum di Indonesia bersifat plural. Akibatnya antara pengikut masing-masing system hukum tersebut sering terjadi tarik menarik (polarisasi) untuk saling member pengaruh, sehingga tidak mudah menjadikan salah satu system hukum sebagai mazhab negara.

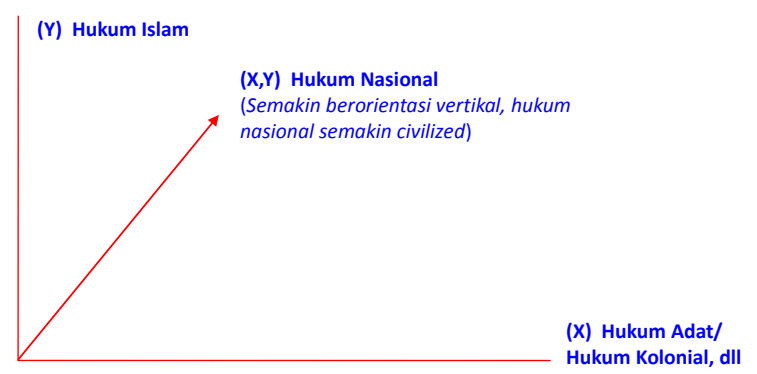

Dengan mendasarkan(QS. Al-Maidah[5]:50), ${ }^{14}$ penulis yakin bahwa hukum Islam adalah hukum yang paling berperadaban. Kenyataan bahwa hukum yang berperadaban (civilized law), sering bertentangan dengan hukum-hukum lainnya (hukum adat istiadat) yang hidup di tengah masyarakat. Adanya pertentangan tersebut disebabkan oleh perbedaan standar kebenaran yang melekat/ menjiwai pada masing-masing norma hukum itu. Diantara masyarakat ada yang berpendapat bahwa standar kebenaran suatu hukum harus mendasarkan pada aspek wahyu, melalui proses kenabian (prophetic), sedangkan masyarakat lainnya cukup hanya mendasarkan pada adat istiadat setempat sebagai bentuk peninggalan nenek moyang. Jika terjadi pertentangan antara keduannya, maka seseorang sebagai warga negara sekaligus mahluk Allah harus berani mengambil sikap untuk menentukan hukum mana yang lebih berperadaban. ${ }^{15}$

Hukum Islam sebelum diadopsi menjadi hukum negara dalam bentuk peraturan perundang-undangan adalah hukum yang berlaku secara non formal. Keberadaan hukum Islam sebagai hukum non formal dapat dijadikan sebagai bahan rujukan utama dalam pembangunan hukum formal di Indonesia. Ketika hukum adat maupun kepercayaan lain terjadi "kekurangan konsep", hukum Islam melalui berbagai produk hukumnya (figh/ fatwa) sudah memuat ketentuan-ketentuan yang berkaitan dengan manusia baik sebagai individu maupun sebagai masyarakat. Kalaupun figh/ fatwa yang ada belum mengatur persoalanpersoalan baru, sesunggunya melalui teori hukum Islam (ushul figh), kekosongan hukum itu bisa segera teratasi. Apalagi hukum yang

\section{QS. Al-Maidah[5]:50.}

${ }^{15}$ Ada beberapa langkah yang perlu dilakukan untuk menentukan hukum yang berperadaban, yaitu: (1) Hukum adat menyesuaikan dengan hukum yang mendasarkan wahyu sebagai representasi kebenaran Ilahi; (2) Dilakukan upaya harmonisasi dengan mengacu pada kaidah bahwa adat sebagai hukum selama tidak bertentangan dengan nash (al 'âdah al muhakamah mâ lam yuhalifu nash); (3) Masing-masing hukum yang hidup di masyarakat dijalankan sendirisendiri secara internal oleh pengikutnya. 
dibutuhkan untuk mengatur persoalan hanya bersifat prosedural, tentu sangat mudah untuk dibuat. Kemudian yang menjadi pertanyaan adalah cara atau mekanisme mengembangkan hukum nasional melalui pendekatan hukum Islam.

\section{Membangun Hukum Nasional Melalui Pendekatan Hukum Islam Teori Penerimaan Hukum Islam}

Hukum Islam di nusantara sudah ada sebelum Indonesia merdeka karena seiring dengan masuknya agama Islam itu sendiri. ${ }^{16}$ Sepanjang kajian sejarah sejak berabad-abad lalu, hukum Islam telah menjadi hukum yang hidup di tengah masyarakat muslim di berbagai belahan dunia termasuk di Indonesia. ${ }^{17}$ Hukum Islam yang dijadikan sebagai panduan kehidupan umat Islam terkondifikasi dalam kitab-kitab figh para ulama. Figh merupakan hasil istinbath hukum para ulama/ fuqaha yang menggunakan metode ushul figh dengan bersumberkan pada al-Qur' an dan as-Sunnah. ${ }^{18}$ Penerimaan hukum Islam di masa kolonial mengalami pasang surut. Hukum Islam melalui Compendium Friejer pernah dijadikan pemerintah kolonial Belanda sebagai hukum positif untuk panduan dasar para hakim dalam menyelesaikan perkara yang berhubungan dengan masyarakat bumi putera di pulau Jawa dan Madura. Disamping

\footnotetext{
${ }^{16}$ Ada yang berpendapat bahwa sejarah hukum Islam di nusantara menurut sebagian ahli sejarah bermula pada abad pertama Hijriah, yaitu sekitar abad ketujuh dan delapan Masehi. Ramly Hutabarat, Kedudukan Hukum Islam dalam Konstitusi-Konstitusi Indonesia dan Peranannya dalam Pembinaan Hukum Nasional (Jakarta: Pusat Studi Hukum Tatanegara Universitas Indonesia, 2005), h. 61
}

${ }^{17}$ Di dalam al-Qur'an, banyak ayat-ayat hukum yang bersifat perintah sehingga harus dijalankan oleh hambahambaNya. Dari sekian banyak perintah tersebut ada yang dapat dijalankan secara perserorangan maupun tidak kecuali melalui jamaah. Perintah Allah yang dibebankan kepada kaum muslimin secara jamaah ada yang dapat dijalankan oleh organisasi Islam secara kelembagaan dan ada yang tidak kecuali oleh negara. Menurut teori, perintah Allah yang dibebankan kepada negara adalah terkait legislasi hukum yang bersifat mengikat.

${ }^{18}$ Imran Ahsan Khan Nyazee, Theories of Islamic Law: The Methodology of Ijtihâd (Islamabad: Islamic Research Institute Press, 1994), h. 22 melalui positiviasi, respon terhadap hukum Islam juga diwujudkan dalam bentuk teori. Diantara respon tersebut ada yang menerima dan ada yang sebaliknya mengesampingkan hukum Islam. Berikut ini adalah dinamika teori penerimaan hukum Islam secara umum yang pernah berlaku di Indonesia.

\begin{tabular}{|c|c|}
\hline $\begin{array}{l}\text { Respon Terhadap } \\
\text { Hukum Islam }\end{array}$ & Substansi Teori \\
\hline $\begin{array}{l}\text { Receptio in } \\
\text { Complexu } \\
\text { Christian Van Den } \\
\text { Berg (1845-1927) }\end{array}$ & $\begin{array}{l}\text { Bagi penduduk beragama } \\
\text { Islam, mereka dikenakan } \\
\text { ketentuan syariah secara } \text { keseluruhan. }^{1}\end{array}$ \\
\hline $\begin{array}{l}\text { Receptie Theorie } \\
\text { Christian Snouck } \\
\text { Hurgronje (1857- } \\
\text { 1936) }\end{array}$ & $\begin{array}{l}\text { Hukum Islam dapat } \\
\text { ditetapkan ditetapkan } \\
\text { sebagai hukum apabila } \\
\text { telah diakui oleh hukum } \\
\text { adat. }^{2}\end{array}$ \\
\hline $\begin{array}{l}\text { Receptie Exit } \\
\text { Hazairin (1906-1975) }\end{array}$ & $\begin{array}{l}\text { Menurut Hazairin teori } \\
\text { resepsi adalah "teori iblis" } \\
\text { karena dimaksudkan untuk } \\
\text { menghapus hukum Islam. }^{3}\end{array}$ \\
\hline $\begin{array}{l}\text { Receptio a } \\
\text { Contrario } \\
\text { Sajuti Talib (1929- } \\
\text { 1990) }\end{array}$ & $\begin{array}{l}\text { Merupakan hasil } \\
\text { pengembangan teori } \\
\text { Receptie Exit yang } \\
\text { diperkenalkan Hazairin }\end{array}$ \\
\hline
\end{tabular}

Membicarakan tentang teori-teori pemberlakuan hukum Islam, maka akan sangat berkaitan dengan proses bagaimana seharusnya nilai-nilai hukum Islam tersebut dapat diadobsi menjadi hukum positif yang berlaku mengikat, tentu disamping mengakui eksistensi hukum adat dan hukum Barat. Adanya politisasi hukum yang dilakukan oleh kolonial Belanda, ternyata selama ini telah mereduksi syariat Islam hingga menjauhkan dari masyarakatnya. Akibatnya, hukum Islam yang seharusnya diterima apa adanya justru cendrung termarjinalkan dalam proses positivasi hukum menurut perspektif tata hukum Indonesia. ${ }^{19}$ Namun di era reformasi, perlakuan tersebut sudah mulai berubah ke arah yang lebih baik.

Eksistensi hukum Islam di Indonesia menurut penulis bisa dilihat dari dua aspek secara umum, yaitu aspek teori (ushul figh) dan aspek produk (figh, fatwa, qadha). Kedua

${ }^{19}$ A. Rahmat Rosyadi dan HM. Rais Ahmad, Formalisasi Syariat Islam dalam Perspektif Tata Hukum Indonesia (Bogor: Ghalia Indonesia, 2006), h. 68 
aspek hukum Islam tersebut sesungguhnya bisa diadopsi menjadi peraturan perundangundangan. Pengadopsian hukum Islam menjadi hukum negara, diperlukan politik hukum (legal policy) yang sejalan dengan visi misi membangun peradaban. Tanpa adanya kesamaan visi misi antara hukum Islam dengan politik hukum yang dijalankan, maka masingmasing akan berjalan sendiri-sendiri, bahkan terkadang saling bertentangan. Artinya antara hukum Islam yang berkembang di masyarakat dengan kebijakan hukum yang dirancang negara akan saling bertentangan. Kenyataan inilah yang sering terjadi di Indonesia ketika membangun hukum negara. Konstribusi hukum Islam dalam pembangunan teori hukum keindonesiaan selain melalui kontekstualisasi ushul figh menjadi teori hukum, juga dapat dilakukan melalui pengadopsian ushul figh dan figh menjadi peraturan perundang-undangan. Ushul fiqh sebagai teori dapat diadopsi ke dalam regulasi tentang penyusunan peraturan perundang-undangan, sedangkan fiqh sebagai produk dapat diadopsi ke dalam peraturan perundang-undangan dari berbagai aspek, seperti perdata, ekonomi, tatanegara, pidana, lembaga pengadilan dan lain-lain termasuk tema-tema hukum kontemporer.

Produk politik hukum di Indonesia adalah ditetapkannya peraturan perundang-undangan sebagai hukum negara. Dalam hal ini, penulis mencoba mengklasifikasikan produk hukum negara menjadi dua, yaitu: (1) Produk hukum yang bersifat prosedural (prosedural law/ hukm al-ijra'i). Produk hukum ini merupakan hasil dari ijtihad yang menggunakan akal. Pendekatan akal digunakan ketika hukum tidak dijumpai secara langsung dari sumbernya. Namun perlu diketahui bahwa pemberlakuan hukum prosedural diperbolehkan selama tidak bertentangan dengan sumber hukumnya; dan (2) Produk hukum yang bersifat substantif (substantive law/ hukm al-syar'i), yaitu produk hukum yang digali langsung dari sumbernya. Sumber dari segala sumber hukum di Indonesia adalah Pancasila. Dalam Pancasila ada sila Ketuhanan yang Maha Esa; dalam Ketuhanan yang Maha Esa ada Al-Qur'an dan Sunnah/
Hadits Rasulullah SAW. Perkembangan hukum Islam di Indonesia bisa dilihat dari keberadaan berbagai produk peraturan perundang-undangan dan produk hukum living law yang hidup di masyarakat (civilized law). Produk peraturan perundang-undangan perkembangannya sangat dipengaruhi oleh aspirasi masyarakat. Dikatakan demikian, karena tidak sedikit tuntutan masyarakat yang ditindaklanjuti oleh lembaga negara untuk mengesahkan peraturan perundangundangan tertentu. Sedangkan perkembangan masyarakat sangat dipengaruhi oleh kemajuan ilmu pengetahuan dan teknologi, serta unsurunsur lainnya termasuk arus globalisasi yang telah mencairkan batas-batas wilayah suatu negara.

\section{Membangun Inside Legal Theory}

Menjalankan hukum sesuai keyakinan (aqidah) merupakan keniscayaan yang tidak bisa terbantahkan. Banyak dasar hukum (dalil-dalil syar'i) yang melegitimasi pernyataan tersebut. ${ }^{20}$ Bahkan perintah itu juga berlaku dalam kitab suci agama samawi lainnya seperti Taurat dan Injil. ${ }^{21}$ Namun kenyataan bahwa masyarakat

${ }^{20}$ Lihat QS.Al-Baqarah[2]: 213, QS.Ali-Imran[3]:23, QS.Al-Maidah[5]:44-45, QS.Al-Maidah[5]: 47-50, dan QS.An-Nisa[4]:59

${ }^{21}$ Dalam Kitab Taurat Musa berkata: “Apabila ada perkara diantara mereka, maka mereka datang kepadaku dan aku mengadili diantara seseorang dan yang lain; lagi pula aku memberitahukan kepada ketetapan-ketetapan dan keputusan-keputusan Allah." [Keluaran (18): 16]. "Berilah keputusan yang adil di dalam perkara-perkara antara seseorang dengan saudaranya atau dengan orang asing yang ada padanya. Dalam mengadili jangan pandang bulu. Baik perkara kecil maupun perkara orang besar harus didengarkan. Jangan gentar terhadap siapapun, sebab pengadilan adalah kepunyaan Allah." [Ulangan (1): 16-17]. Maka lakukan kewajibanmu dengan setia kepada Tuhan, dengan hidup menurut jalan yang telah ditunjukkannya dan dengan tetap mengikuti segala ketetapan, perintah dan ketentuannya, seperti yang telah tertulis dalam hukum Musa (Taurat). [I Raja-Raja (2): 3]. Dalam Kitab Injil Nabi Isa as berkata: "Janganlah kamu menyanagka bahwa aku (Isa) datang untuk meniadakan hukuman Taurat, melainkan untuk melengkapinya.....karena itu siapa yang meniadakan salah satu perintah hukum Taurat sekalipun yang paling kecil, dan mengajarkannya demikian kepada orang lain, maka ia akan menduduki tempat paling rendah (Neraka)" [Matius (5): 17-20]. Seruan dari kutipan ayat-ayat di atas merupakan bukti pentingya supremasi hukumhukum Allah sepanjang sejarah. Namun dari hasil analisa, dalam kitab suci agama samawi pra Islam itu, belum dijumpai adanya penjelasan lebih lanjut secara 
plural sering dianggap sebagai kendala pemberlakuan hukum Islam. pemberlakuan hukum agama sering dianggap bertentangan dengan prinsip kebinekaan/ keberagamaan. Pertanyaannya, mungkinkan hukum Islam berlaku di tengah masyarakat yang plural seperti di Indonesia?

Keberagaman (pluralitas) merupakan sunatullah. ${ }^{22}$ Di tengah keberagaman tersebut, Allah telah menurunkan wahyuNya sebagai sumber hukum untuk diamalkan. Karena itu antara hukum Islam dengan keberagaman sebagai sunatullah tidak perlu dipertentangkan. Mempertentangkan antara keduanya merupakan kesalahan, sebab sama artinya dengan menolak pemberlakuan hukum. Akibatnya, hukum Islam yang seharusnya diposisikan sesuai kehendakNya justru termarjinalkan. Padahal untuk menghormati keberagaman tidak harus mengorbankan hukum Islam itu sendiri. Untuk memberlakukan hukum sesuai dengan agama dan kepercayaannya masing-masing diperlukan suatu teori. Teori tersebut harus mengakomodasi berlakunya hukum agama dalam suatu Negara. Islam sebagai salah satu agama telah mengajarkan berbagai hukum kepada umatnya untuk diamalkan. Namun agar berlakunya hukum Islam tidak mengganggu keyakinan agama lain, maka berlakunya hukum Islam maupun hukum agama lainnya harus berlaku ke internal. Karena hukum Islam berlaku secara internal bagi umat Muslim sendiri, maka penulis istilahkan dengan Inside Legal Theory.

Inside Legal Theory adalah teori pemberlakuan hukum secara internal bagi umatnya masingmasing. Masing-masing agama dipersilahkan "berkompetisi" dalam mencapai kebaikan melalui pemberlakuan hukum yang mereka miliki. Dari hasil hepotesis, Islam merupakan agama yang paling siap untuk memberlakukan hukum di setiap lini kehidupan. Teori hukum Islam tidak khawatir dengan adanya perubahan masyarakat. Bahkan hukum Islam mendorong

mendetail tentang akad-akad kontrak perjanjian.

22

QS.Al-Hujurat [49]: 13 umatnya untuk berperadaban paling modern (civilized), dengan syarat selama mereka berada dalam kerangka norma-norma syariat Allah. Berlakuanya Inside Legal Theory tidaklah bertentangan dengan al-Qur'an. Allah berfirman: "Untuk tiap-tiap umat diantara kamu, Kami berikan aturan (hukum) dan jalan yang terang" (QS. Al-Maidah[5]: 48). Artinya sesungguhnya Allah telah menurunkan hukum bagi masingmasing agama samawi (taurat dan injil). Hukumhukum tersebut kemudian disempurnakan dalam kitab suci al-Qur'an untuk diberlakukan kepada seluruh umat manusia. Hukum yang digali dari al-Qur'an inilah yang kemudian menjadi hukum substantif yang berlaku bagi internal umat Muslim. Contoh implementasi hukum substantive yang berlaku ke dalam adalah Pasal 2 Ayat (1) Undang-Undang Perkawinan yang menyatakan: "Perkawinan adalah sah apabila dilakukan menurut hukum masing-masing agama dan kepercayaannya itu." Namun pendekatan semacam ini tidak dapat berlaku keseluruhan, kecuali bidangbidang tertentu saja yang secara tegas diatur dalam kitab suci, misalnya jarimah hudud, qishas, kewarisan, haji, zakat, waqaf, keajiban berbusana muslim, larangan ber-khalwat selain muhrim, murtad, dan lain-lain yang bersifat internal.

Dalam suatu peraturan perundang-undangan, selain memuat hukum substantive juga dapat memuat hukum yang bersifat prosedural. Contoh implementasi hukum yang bersifat prosedural adalah Pasal 2 Ayat (2) UndangUndang Perkawinan yang menyatakan: “Tiaptiap perkawinan dicatat menurut peraturan perundang-undangan yang berlaku." Bahkan dalam satu peraturan perundang-undangan boleh saja keseluruhan materinya memuat hukum substantive atau hukum yang bersifat prosedural. Misalnya undang-undang lalu lintas, undang-undang kependudukan, dan lain-lain, tentu keseluruhan materinya bersifat prosedural karena tidak digali langsung dari kitab suci. 


\section{Kesimpulan}

Hukum Islam sangat memungkinkan untuk memberikan konstribusi dalam pembangunan hukum nasional Indonesia baik melalui pendekatan akademik maupun politik. Pendekatan akademik dilakukan dengan cara pengembangan ilmu pengetahuan hukum Islam dan penyebarluasannya kepada masyarakat. Sedangkan dari aspek politik adalah dengan mengadopsi konsep-konsep hukum Islam

\section{DAFTAR PUSTAKA}

Al-Qur'an dan Terjemahannya

Ali, Muhammad Daud. Bangunan-Bangunan Islam. Jakarta: Penerbit Bintang. 1968

Dahlan, Abd. Rahman. Ushul Figh. Jakarta: Penerbit Amzah. 2010

Ehrlich, Eugen. Fundamental Principles of Sociology of Law. Cambridge: Harvard University Press. 1936

Hazairin. Tujuh Serangkai Tentang Hukum Islam. Jakarta: Penerbit Tintamas. 1974

Hutabarat, Ramly. Kedudukan Hukum Islam dalam Konstitusi-Konstitusi Indonesia dan Peranannya dalam Pembinaan Hukum Nasional. Jakarta: Pusat Studi Hukum Tatanegara Universitas Indonesia. 2005

Nyazee, Imran Ahsan Khan. Theories of Islamic Law: The Methodology of Ijtihâad. Islamabad: Islamic Research Institute Press. 1994 hidup di masyarakat menjadi peraturan perundang-undangan. Berdasarkan Inside Legal Theory, pemberlakuan hukum Islam secara yuridis formal tidak bertentangan dengan prinsip kebinekaan/ keberagaman. Begitupula sebaliknya, larangan terhadap pemberlakuan hukum Islam merupakan bentuk pelanggaran terhadap sila ke-1 Pancasila dan pembukaan alinea ketiga dan keempat, serta batang tubuh Pasal 29 UUD 1945.

Pound, Roscoe. Interpretation of Legal History. Harvard University Press. 1946

Rosyadi, A. Rahmat dan HM. Rais Ahmad. Formalisasi Syariat Islam dalam Perspektif Tata Hukum Indonesia. Bogor: Ghalia Indonesia. 2006

Sinha, Surya Prakash. Jurisprudence Legal Philosophy in A Nutshell. West Publishing Co. 1993

Syarifuddin, Amir. Ushul Figh I. Jakarta: Kencana. 2011

Thalib, Sajuti. Hubungan Hukum Adat dengan Hukum Islam. Jakarta: Bina Aksara. 1985

Toomey, Ling. Communicating Across Culture. New York: The Gulford Press. 1999

Undang-Undang Nomor 12 Tahun 2011 tentang Pembentukan Peraturan Perundang Undangan 